\title{
The Geography, Economics, and Politics of Lottery Adoption
}

\author{
Cletus C. Coughlin, Thomas A. Garrett, and Rubén Hernández-Murillo
}

\begin{abstract}
Since New Hampshire introduced the first modern state-sponsored lottery in 1964, 41 other states plus the District of Columbia have adopted lotteries. Lottery ticket sales in the United States topped $\$ 48$ billion in 2004 , with state governments reaping nearly $\$ 14$ billion in net lottery revenue. In this paper the authors attempt to answer the question of why some states have adopted lotteries and others have not. First, they establish a framework for analyzing the determination of public policies that highlights the roles of individual voters, interest groups, and politicians within a state as well as the influence of policies in neighboring states. The authors then introduce some general explanations for the adoption of a new tax that stress the role of economic development, fiscal health, election cycles, political parties, and geography. Next, because the lottery adoption decision is more than simply a tax decision, a number of factors specific to this decision are identified. State income, lottery adoption by neighboring states, the timing of elections, and the role of organized interest groups, especially the opposition of certain religious organizations, are significant factors explaining lottery adoption.
\end{abstract}

Federal Reserve Bank of St. Louis Review, May/June 2006, 88(3), pp. 165-80.

otteries have had a turbulent history in the United States. ${ }^{1}$ In early America, lotteries were used by all 13 colonies to finance improvements in infrastructure, such as bridges and roads. Both during and after the Revolutionary War, lotteries were used to provide support for the military (e.g., the Continental Army), public projects, and the financing of private universities, such as Harvard. These early lotteries were closer to a raffle than to the modern concept of a lottery. Private lotteries began operating in the mid-1800s, with many of these lotteries operating through the mail system. As a result of corruption and a growing public distrust of lotteries, the federal government prohibited all interstate lottery commerce in the early 1890s.

1 See Clotfelter and Cook (1989 and 1990) for an extensive history of state lotteries.
As a result of this federal prohibition and growing public distrust, the majority of states enacted explicit constitutional prohibitions against lotteries of any form. By 1894 no state allowed the operation of a lottery. ${ }^{2}$

Lotteries remained illegal in the United States for almost 70 years. In the early 1960s, however, New Hampshire had a lottery referendum that allowed the citizens of New Hampshire to vote for or against a state-sponsored lottery. Not only was New Hampshire the first state to propose the legalization of lottery gambling after 70 years of nationwide prohibition, it was the first modern attempt at state-run gambling. The voters of New Hampshire decided in favor of a lottery, with 76 percent of public votes in favor of adoption. In 1964, New Hampshire became the first state to

\footnotetext{
2 See Blanch (1949).
}

Cletus C. Coughlin is deputy director of research, Thomas A. Garrett is a research officer, and Rubén Hernández-Murillo is a senior economist at the Federal Reserve Bank of St. Louis. Lesli Ott provided research assistance.

(C) 2006, The Federal Reserve Bank of St. Louis. Articles may be reprinted, reproduced, published, distributed, displayed, and transmitted in their entirety if copyright notice, author name(s), and full citation are included. Abstracts, synopses, and other derivative works may be made only with prior written permission of the Federal Reserve Bank of St. Louis. 
offer a lottery. Since that time, 41 additional states and the District of Columbia have adopted state-sponsored lotteries. ${ }^{3}$ North Carolina adopted a lottery in the summer of 2005, leaving only Alabama, Alaska, Arkansas, Hawaii, Mississippi, Nevada, Utah, and Wyoming without a lottery.

Coinciding with the more frequent use of lotteries has been a rise in both lottery purchases and the importance of lottery revenue as a percentage of state revenue. Lottery ticket sales in 2004 topped $\$ 48$ billion, or about 0.5 percent of total national income. ${ }^{4}$ Of this $\$ 48$ billion in sales, states received nearly $\$ 14$ billion in net lottery revenue (i.e., revenue available to state governments after the deduction of prizes, commissions, and administration costs). ${ }^{5}$ In terms of national per capita spending, lottery sales amounted to roughly $\$ 166$ per person in 2004 . Net lottery revenue as a share of total state government revenue rose from 0.35 percent in 1980 to 1.22 percent in 2002.

The spread of state lotteries coincides with changing attitudes toward legalized gambling, growing state and local government expenditures, and growing public opposition to both new taxes and increased rates for existing taxes (Fisher, 1996). Arguably, lotteries are a more politically attractive means of generating additional revenue than increasing rates on existing tax bases.

Although this premise may explain the initial interest in modern lotteries, it fails to adequately explain the uneven rate of lottery adoption over

\footnotetext{
3 Many states have entered into multistate lottery games, such as PowerBall. Multistate games pool ticket revenue from participating states to offer much larger jackpots (at more remote odds of winning) than single-state lottery games. Since 1964, states' participation in multistate games has increased. One likely reason for this increased participation is to maintain players' excitement about lottery games in the face of increased competition from casino gaming. See Hansen (2004) for a description of the various types of lottery games, including multistate lottery games.

4 Several states, such as Delaware and West Virginia, operate video lottery terminals at pari-mutuel racetracks. These venues are similar to casinos and generate hundreds of millions of dollars annually. Clearly, this form of lottery differs from the traditional scratch-off or numbers game lottery. Sales figures presented here include both traditional lottery sales and video lottery sales.

5 On average, states allocate 50 percent of sales to lottery prizes and 20 percent to administrative costs and retailer commissions. The remaining 30 percent is retained by the state. Hansen (2004) notes, however, that the shares for prizes and administrative costs vary by state.
}

the past 40 years (see Table 1). For example, between 1964 and 1975, 14 states adopted lotteries. No states adopted lotteries in the late 1970s, 18 states adopted lotteries in the 1980s, and 6 states adopted a lottery in the 1990s.

In this paper, we focus on the question of why most states have adopted lotteries and why some states have yet to adopt a lottery. The growth in government and relaxed moral views of gambling may be a partial answer to this question, but these reasons are too broad, as they ignore the political and economic realities of public policy formulation. We review the literature on lottery adoption and, more importantly, public policy adoption in general to understand which factors drive policy formation. As the title of our paper suggests, lottery adoption is the result of geographic, economic, and political factors.

\section{THE POLITICAL ECONOMY OF PUBLIC POLICIES}

Public policy decisions result from the interaction of various factors. Before examining the factors that play a role in lottery adoption, we provide a framework for analyzing public policy decisions in general. Figure 1 highlights the primary actors and the legislative decision process in the democratic determination of a public policy. ${ }^{6}$ Similar to the demand and supply for a good, there also exists a demand side and a supply side for legislation, in this case the adoption of a state lottery. On the demand side, one starts with the opinions that individuals possess concerning the adoption of a lottery (see box A in Figure 1). The opinion of an individual is likely to be related to numerous considerations, such as income, education, age, potential impact of the legislation, and moral values.

A common feature of any political decision in the United States is that interest groups are involved. Because of the intensity of opinions on an issue and the importance (economic and otherwise) of the issue, interest groups form and attempt

\footnotetext{
${ }^{6}$ Our framework is based on ideas presented by Rodrik (1995) in the context of the political economy of trade policy.
} 


\section{Table 1}

\section{State Lottery Adoption}

\section{State}

Arizona

California

Colorado

Connecticut

Delaware

District of Columbia

Florida

Georgia

Idaho

Illinois

Indiana

lowa

Kansas

Kentucky

Louisiana

Maine

Maryland

Massachusetts

Michigan

Minnesota

Missouri

Montana

Nebraska

New Hampshire

New Jersey

New Mexico

New York

North Carolina

North Dakota

Ohio

Oklahoma

Oregon

Pennsylvania

Rhode Island

South Carolina

South Dakota

Tennessee

Texas

Vermont

Virginia

Washington

West Virginia

Wisconsin

\section{Start date}

July 1, 1981

October 3, 1985

January 24, 1983

February 15, 1972

October 31, 1975

August 22, 1982

January 12, 1988

June 29, 1993

July 19, 1989

July 30, 1974

October 13, 1989

August 22, 1985

November 12, 1987

April 4, 1989

September 6, 1991

June 27, 1974

May 15, 1973

March 22, 1972

November 13, 1972

April 17, 1990

January 20, 1986

June 27, 1987

September 11, 1993

March 12, 1964

December 16, 1970

April 27, 1996

June 1, 1967

March 30, 2006

March 25, 2004

August 13, 1974

October 12, 2005

April 25, 1985

March 7, 1972

May 18, 1974

January 7, 2002

September 30, 1987

January 20, 2004

May 29, 1992

February 14, 1978

September 20, 1988

November 15, 1982

January 9, 1986

September 18, 1988

\section{Method of approval}

Initiative

Initiative

Initiative

Legislation

Legislation

Initiative

Referendum

Referendum

Referendum

Legislation

Referendum

Legislation

Referendum

Referendum

Referendum

Referendum

Referendum

Legislation

Referendum

Referendum

Referendum

Referendum

Referendum

Legislation

Referendum

Legislation

Referendum

Legislation

Referendum

Legislation

Referendum

Initiative

Legislation

Referendum

Referendum

Referendum

Referendum

Referendum

Referendum

Referendum

Legislation

Referendum

Referendum

SOURCE: Hansen (2004); North Carolina and Oklahoma information from news reports. 


\section{Figure 1}

\section{The Determination of a Public Policy: Lottery Adoption}

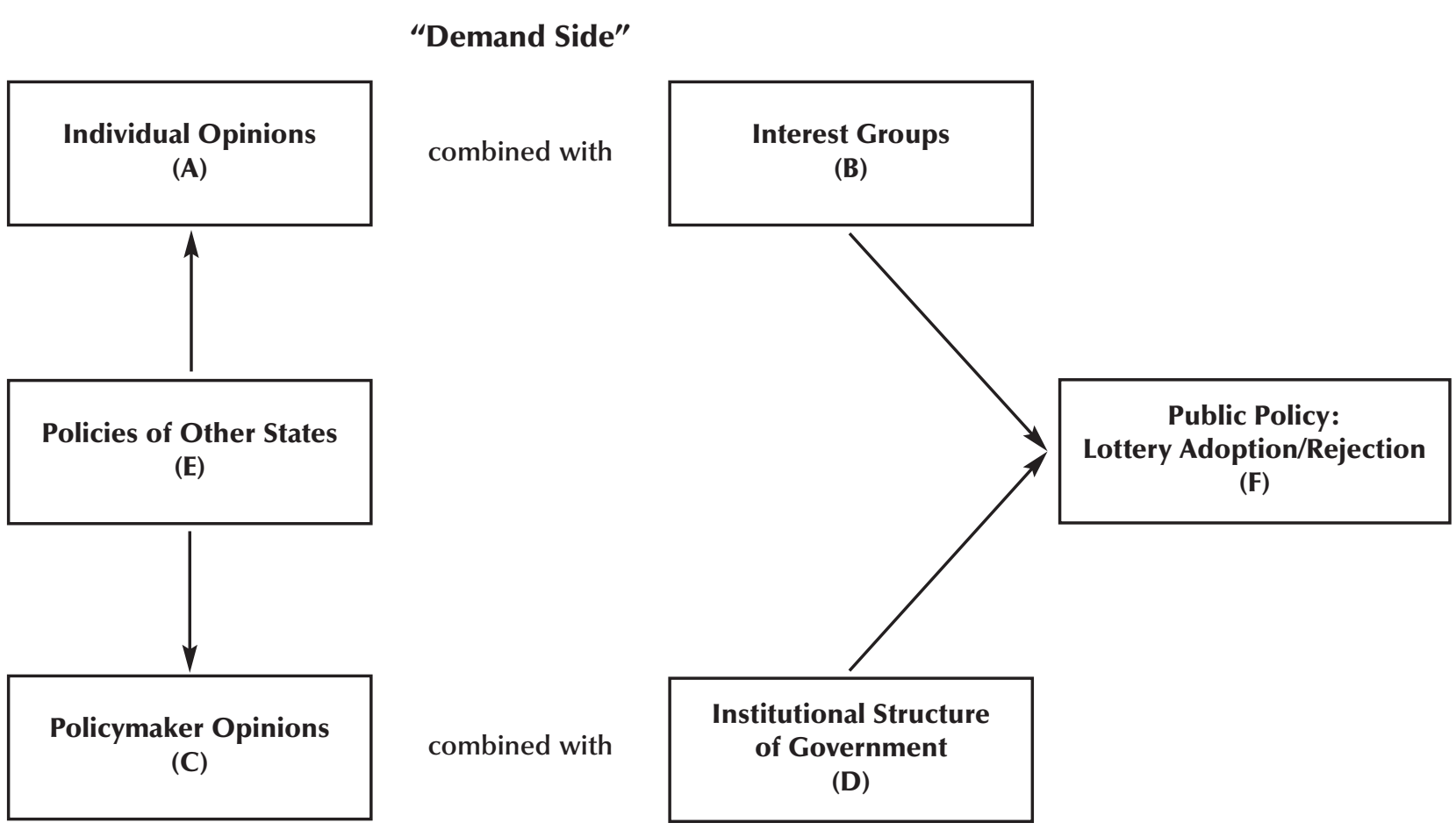

\section{"Supply Side"}

to influence the political decision (see box B in Figure 1). Through lobbying and contributions, interest groups attempt to affect the positions of representatives voting on the legislation. ${ }^{7}$ In addition, they attempt to increase popular support for their position as well. Thus, individual opinions and interest groups determine the demand side of the market for a public policy. ${ }^{8}$

On the supply side, one starts with the opinions of policymakers (see box C in Figure 1). These

\footnotetext{
7 McCormick and Tollison (1981) model an interest group economy using supply and demand analysis. Becker (1983) presents a theory of public policy formation that results from competition among special interest groups.

8 In Figure 1, we separate the demand side from the supply side for clarity in presentation. Because interest groups attempt to influence policymakers directly, we could have drawn a line from box B to box C. For illustrative purposes, one can think of such influence as playing itself out through the interaction of demand and supply.
}

policymakers include the legislators and those in the executive branch who can affect the legislation. Because the majority of these policymakers are elected representatives who, in many cases, wish to be re-elected, it is reasonable to anticipate that their positions will reflect to some degree the preferences of those who have elected them. As mentioned previously, interest groups also attempt to influence the positions of policymakers and are frequently involved in the drafting of legislation. ${ }^{9}$

The other consideration on the supply side is the institutional structure of government (see box D in Figure 1). Legislation is not simply proposed and then voted on, but rather it must work its way through a legislative process. As a piece of legislation is subjected to the scrutiny of legisla-

\footnotetext{
${ }^{9}$ See Bonner (2005).
} 
tive committees, the legislation may well be modified. The institutional structure of government might also affect the support for a piece of legislation by means of the trading of support that occurs between legislators. The extent to which a specific party is in control also might affect political support for the adoption of a lottery.

Finally, the decisions made by policymakers and voters in a specific state may affect the decisions of other states (see box E in Figure 1). ${ }^{10}$ Geography as well as economics may come into play because the economic effects stemming from a specific state's lottery may be more pronounced for nearby states. As a result, citizens and decisionmakers in nearby states may feel they must take a similar action (i.e., in this case, also adopt a lottery) as a form of self-defense. The prior adoption by another state may also provide information on the consequences of such legislation, which may influence the positions of individuals and policymakers.

Ultimately, the various factors mentioned above interact to produce a decision. In the present case, the public policy decision is whether to adopt or reject a state lottery (see box F in Figure 1). ${ }^{11}$ As shown in Table 1, the precise method of approval of lotteries varies across states. Many states use a statewide referendum as part of the adoption process. ${ }^{12} \mathrm{~A}$ referendum is a popular vote on an issue already approved by a legislative body, with the final decision made by the electorate rather than by their representatives. Instead of a referendum, some states have adopted lotteries through the initiative process. The initiative process enables a specified number of voters to propose a law by petition. In the case of California, Proposition 37 was submitted to California's voters, who approved the law. Finally, lottery adoption in several states, most recently North Carolina, simply required approval by each state's

\footnotetext{
${ }^{10}$ For example, Hernández-Murillo (2003) provides evidence of tax competition across states and Garrett, Wagner, and Wheelock (2005) present empirical evidence of cross-state dependence in banking deregulation.

${ }^{11}$ Hersch and McDougall (1988) and Garrett (1999) explore legislative voting behavior on the issue of state lottery adoption.

${ }^{12}$ Hansen (2004) notes that many states required a referendum or an initiative to remove a state constitutional ban on lotteries.
}

legislature and governor without a direct citizen vote. $^{13}$

\section{THE ADOPTION OF NEW TAXES}

Without question, the issues surrounding the adoption of a tax are similar to those for the adoption of a lottery; however, the adoption of a lottery entails more than (and is quite different from) simply authorizing a new tax. Lottery adoption involves legalizing a previously illegal activity, from which a state will generate revenue. Furthermore, consumer participation in the lottery is strictly voluntary; it is possible, then, that those who are opposed to the lottery might not oppose the legislation because they can decline to play the lottery, whereas it is more complicated and potentially illegal to decline to pay a tax. ${ }^{14}$ Also, one's position on lottery adoption as a means to raise revenues might be overwhelmed by other considerations. Therefore, our discussion of lottery adoption must go beyond an explanation of adopting a new tax: In fact, our discussion integrates all these considerations and others after examining some literature on the adoption of new taxes.

Hansen (1983) develops a theory of taxation highlighting the role of political incentives, many of which apply to the lottery adoption process. According to Hansen, politicians make decisions with an eye toward retaining their positions. Economic considerations come into play in the adoption of new taxes by affecting the political incentives. For example, the existence of an economic crisis may reduce the political risks of approving new taxes, whereas new taxes are unlikely to gain approval if a state has a budgetary surplus on the horizon. In the absence of crises, separating taxpayers from their incomes/wealth is an unwise electoral strategy. Even with a crisis, however, Hansen stresses the importance of politi-

\footnotetext{
13 The initiative is similar to a referendum; however, policymakers have a more limited role in the approval of lottery adoption if the initiative process is used, compared with either a referendum or standard legislative process.

${ }^{14}$ Arguably, paying sales and income taxes is voluntary if one chooses not to purchase consumer goods or work.
} 
cal parties' control of government for implementing tax policy. A unified government is crucial for providing the political opportunity for adopting a new tax.

Capitalizing on political opportunity is an issue Berry and Berry (1992) take up. They identify the following categories of explanations for the adoption of new taxes, or what is often termed as a tax innovation: (i) economic development, (ii) state fiscal health, (iii) election cycles, (iv) political party control, and (v) regional diffusion. The economic development explanation suggests that a state's level of economic development affects the likelihood of adopting a tax. More-developed states are likely to have a combination of tax capacity and demand for public services that lead to tax adoption. ${ }^{15}$ The fiscal health explanation suggests that the existence of a fiscal crisis, such as a large budget deficit, increases the probability of approving a new tax. The crisis reduces the political risks for politicians of a tax innovation. Similar reasoning is used in the election cycle explanation. Tax increases are unpopular; therefore, elected officials do not innovate in election years. The party control explanation has two propositions. First, if the party in control is a liberal party, the adoption of a new tax is more likely. Second, a state in which the same party controls the governorship and the legislative bodies (i.e., a unified government) is more likely to adopt a tax than a state with a divided government. The fifth explanation, the regional diffusion explanation, suggests that states emulate the tax policies adopted by others. Political scientists have stressed that prior adoptions provide information and make the tax increase easier to sell to constituents. In addition, in the context of lotteries, adoption by a state puts competitive pressures on nearby states because some of its lottery tax revenues are due to attracting players from nearby states.

\footnotetext{
${ }^{15}$ As described in Filer, Moak, and Uze (1988), the Advisory

Commission on Intergovernmental Relations uses a "representative tax system" to calculate tax capacity. Tax capacity is the revenue that each state would raise if it applied a uniform set of rates to a common set of tax bases. The uniform set of rates is the average rates across states for each of 26 taxes. Using the same rates for every state causes potential tax revenue for states to vary only because of differences in underlying tax bases. A state's "tax capacity index" is its per capita tax capacity divided by the average for all states.
}

A sixth category for explaining the adoption of a lottery not discussed by Berry and Berry (1992) considers the alternatives and constraints facing policymakers and the factors that apply specifically to the approval of a lottery. We use the term "situational-specific determinants" to describe this category. When faced with pressures to increase revenues, policymakers examine a range of possibilities that include increasing the rates of existing taxes, expanding what is taxable, as well as adopting and implementing new taxes. ${ }^{16}$ The ability of policymakers to increase revenues may be limited by prior political decisions and by a state's economic circumstances that are beyond economic development and fiscal health. For example, a state that has no sales tax is likely to face different political constraints than a state with a sales tax. Increasing a sales tax rate from 0 to 1 percent, which requires adopting and implementing a sales tax, is likely much different from increasing a sales tax rate from 4 to 5 percent.

\section{FRAMEWORKS FOR ANALYZING THE LOTTERY ADOPTION DECISION}

Various conceptual frameworks have been used to model state lottery adoption, but they all rely on rational behavior by legislators. What differentiates the frameworks is the objective function of the legislator. The most frequently used framework is the legislator-support maximization approach (see Filer, Moak, and Uze, 1988). The position on lottery adoption that a given legislator takes reflects an attempt to maximize re-election prospects. Legislators recognize that increased state spending can increase their political support by increasing the well-being of their constituents. Note that it is through political support that the demand side of the determination of a public policy is incorporated. Spending cannot be raised, however, without some loss of support due to the increased tax burden placed on their constituents. This trade-off guides how the legislator votes on specific issues. For a legislator to vote in favor of

\footnotetext{
${ }^{16}$ Of course, cutting spending is also an option to deal with an imbalance between spending and revenues.
} 
a specific proposal, the increase in support associated with the spending must exceed the decrease in support associated with the taxes.

A second framework, Martin and Yandle's (1990) duopoly transfer mechanism approach, views the state government as a rent-seeker and a redistributive agent. Lotteries compete with both legal and illegal gambling operations. A state-run lottery provides a mechanism that allows the state to generate some revenues that they miss by not being able to tax illegal operations. A closely related issue is why lotteries are organized as a state enterprise as opposed to allowing private firms to freely enter and provide lottery services in a competitive environment. One answer is that the revenues for the state from a state-run lottery are likely to exceed the revenues that the state would generate from allowing private firms to enter the lottery market and then taxing the profits of these firms. In Martin and Yandle's (1990) approach, the state achieves equilibrium with the illegal operators. Moreover, lotteries provide a way for higher-income voters to redistribute the tax burden associated with state spending from themselves to lower-income groups. ${ }^{17}$

A third framework, in Erekson et al. (1999), assumes the legislator maximizes utility subject to a constraint. The legislator reflects the median voter because of the decisive role of this voter in producing a majority. The legislator receives utility from improving the state's fiscal well-being, but the legislator is constrained, similar to the constraint in the legislator-support maximization approach, by his re-election desires that hinge on the satisfaction of his constituents.

The empirical implementation of these frameworks has proceeded in two ways. Filer, Moak, and Uze (1988), Martin and Yandle (1990), and Davis, Filer, and Moak (1992) address the question of whether a state has a lottery as of a specific year. Filer, Moak, and Uze (1988) and Davis, Filer, and Moak (1992) estimate binary choice probit models, while Martin and Yandle (1990) use ordinary least squares. These studies identify and then examine statistically a number of variables that are related to whether a state has a lottery as of a

${ }^{17}$ Note that, despite the focus on state government, there is still a demand role played by the state's citizens. specific year. The other approach, using hazard or duration models, provides evidence on which variables increase or decrease the likelihood that a state adopts a lottery. Using this approach, the variable to be explained is termed the hazard rate, which is the probability that a state without a lottery will in fact adopt a lottery during a specific time period, generally a calendar year. ${ }^{18}$

\section{WHY SOME STATES HAVE LOTTERIES AND OTHERS DO NOT}

Using the tax innovation explanations put forth by Berry and Berry (1992) that were discussed earlier, this section sheds light on the question of why some states have lotteries and others do not.

\section{Economic Development}

With respect to the level of economic development, higher levels of per capita state income are associated with (i) an increased probability that a state has a lottery as of a specific date and (ii) a shorter time until a state adopts a lottery. ${ }^{19} \mathrm{~A}$ common argument rationalizing this result is based on the finding that lotteries tend to be a regressive form of taxation. In other words, evidence suggests that those with low incomes bear a relatively higher lottery tax burden than those with high incomes. ${ }^{20}$ In their report to the National Gambling Impact Study Commission, Clotfelter et al. (1999) provide evidence that low-income groups spend a larger share of their incomes on the lottery and that they also spent more in absolute terms. ${ }^{21}$ For example, those with an annual house-

${ }^{18}$ Berry and Berry (1990), Alm, McKee, and Skidmore (1993), Caudill et al. (1995), Mixon et al. (1997), Erekson et al. (1999), and Glickman and Painter (2004) estimate hazard functions in their lottery adoption studies.

${ }^{19}$ See Davis et al. (1992), Martin and Yandle (1990), Berry and Berry (1990), Caudill et al. (1995), Mixon et al. (1997), Erekson et al. (1999), and Glickman and Painter (2004).

${ }^{20}$ There is some evidence that high jackpot lottery games, such as PowerBall, may be less regressive than lower jackpot games. See Oster (2004)

${ }^{21}$ This latter finding suggests that lottery tickets are inferior goods (e.g., the income elasticity of demand for lottery tickets is negative). Although most studies have found lotteries to be regressive, most have not found lotteries to be inferior goods. See Clotfelter and Cook (1989 and 1990) and Fink, Marco, and Rork (2004) for a survey of the literature. 
hold income of less than $\$ 10,000$ spent $\$ 597$ on lotteries on a per capita basis and those with a household income of between $\$ 10,000$ and $\$ 24,999$ spent $\$ 569$. This spending was substantially more than spending by those with a household income of between $\$ 25,000$ and $\$ 49,999$ (\$382), between $\$ 50,000$ and $\$ 99,999$ (\$225), and over $\$ 100,000$ (\$196).

In light of the regressive nature of lotteries, it has been argued that a legislator with a lowincome constituency is more likely to oppose raising funds by means of a lottery than a legislator with a high-income constituency. ${ }^{22}$ Martin and Yandle (1990) stress this redistributive feature by arguing that lotteries are a mechanism for higherincome voters to redistribute tax burdens in their favor. Thus, states with higher per capita incomes are more likely to have lotteries. ${ }^{23}$ In addition to the redistribution argument, Berry and Berry (1990) and others stress that higher per capita income is associated with more revenue potential from a lottery. However, if higher-income households in fact spend less on lotteries than lowerincome households, then the revenue potential from a lottery may decline as per capita income rises.

The connection between revenue potential and lottery adoption has been explored by Filer, Moak, and Uze (1988). They argue that states with a larger urban population are more likely to have lotteries than more rural states because of relatively lower administrative costs. ${ }^{24}$ More densely populated states will tend to have more potential purchasers per lottery outlet and generate a relatively

\footnotetext{
22 This argument assumes that legislators with low-income constituencies take such a position for paternalistic reasons (rather than from a desire to represent the views of their constituents). Legislators with high-income constituencies, on the other hand, take a position in line with the views of their constituents. A related argument is that low-income groups with poor economic prospects may place a relatively higher discount on lottery losses than high-income groups. Lotteries offer a small prospect for a large gain for those who play. Representatives of low-income constituents could vote to restrict lotteries to inhibit these constituents from gambling away their minimal resources.

${ }^{23}$ Filer, Moak, and Uze (1988) use a measure of the percentage of poor within a state and find this measure to be a negative and statistically significant determinant of lottery adoption.

${ }^{24}$ DeBoer (1985) examines the economies of scale in state lottery production.
}

greater value of revenue per dollar of administrative costs. Filer, Moak, and Uze find that the percentage of a state's population that is urban is related positively to lottery adoption, while Alm, McKee, and Skidmore (1993), Caudill et al. (1995), and Glickman and Painter (2004) find that state population density is related positively to lottery adoption. However, Caudill et al. (1995) and Mixon et al. (1997) fail to find a statistically significant relationship between a measure of predicted lottery profits and lottery adoption. The empirical evidence examining the connection between total population and lottery adoption is also mixed.

Alm, McKee, and Skidmore (1993) find a positive and statistically significant relationship between state population and lottery adoption, but Filer, Moak, and Uze (1988) and Glickman and Painter (2004) do no find a statistically significant relationship.

Another measure of economic development that has been examined for its statistical relationship to lottery adoption is per-pupil state education spending. Lottery adoption often occurs as part of a promise to earmark lottery proceeds to finance spending on education. Thus, states with lagging education spending are more likely to support such earmarking. Second, the current lack of education spending portends a bleak economic future that motivates a state to take action to alter the future. Erekson et al. (1999) find a statistically significant, negative relationship between per-pupil education spending and the decision to adopt a lottery. ${ }^{25}$

\section{Fiscal Health}

The fiscal health explanation suggests that the existence of a fiscal crisis, such as a large budget deficit, increases the probability of approving a new tax or, similarly, a state lottery. Numerous variables have been used to measure a state's fiscal health. A measure used by two early studies was

\footnotetext{
${ }^{25}$ Although net lottery revenue is earmarked for public education in many states, there is little evidence that the earmarking of lottery revenue has increased education expenditures. The reason for this is that state legislators divert funds away from education and simply replace these diverted funds with net lottery revenues, thus leaving total education expenditures unchanged. See Spindler (1995) and Garrett (2001).
} 
the Advisory Commission on Intergovernmental Relations' tax effort. This measure is a ratio of a state's tax collections relative to its capacity of tax revenue. Larger values of this measure are thought to indicate that a state was making an increased effort to generate tax revenues. As this measure becomes larger, the odds increase that a state will seek additional revenue sources. Both Filer, Moak, and Uze (1988) and Davis, Filer, and Moak (1992) find that the higher a state's tax effort, the larger the probability the state has a lottery.

Rather than use tax effort, some studies have simply used per capita state tax revenues. Martin and Yandle (1990) argue that higher per capita state taxes are an indicator of tax pressures, and, thus, higher levels provide an increased incentive to find a way to relieve the pressure. Martin and Yandle (1990) argue that one way to simultaneously relieve the pressure and increase tax revenues is to shift the relative tax burden from higher- to lower-income taxpayers by means of a lottery. They found that higher per capita state taxes were associated with lottery adoption. On the other hand, Caudill et al. (1995) and Mixon et al. (1997) do not find a statistically significant relationship between per capita state taxes and the probability that a state adopts a lottery in a given time period.

Another commonly used measure of fiscal health is per capita state debt. Higher levels of debt raise increased doubts about a state's fiscal health. As put forth in Martin and Yandle (1990), higher debt will result in a larger demand for shifting taxes to lower-income groups; such pressures make lotteries more likely. Martin and Yandle (1990) find a positive and statistically significant relationship between per capita state debt and lottery adoption. However, numerous other studies, such as Caudill et al. (1995), Mixon et al. (1997), and Glickman and Painter (2004), do not find a statistically significant relationship between per capita state debt and the probability that a state will adopt a lottery within a given period. On the other hand, when Alm, McKee, and Skidmore (1993) separate overall debt into short-term and long-term debt, they find a statistically significant, positive relationship between short-term state debt and lottery adoption, but no such statistically significant relationship between long-term state debt and lottery adoption.

Rather than looking at overall debt, Berry and Berry (1990) and Erekson et al. (1999) examine the difference between state revenue and spending relative to spending as a measure of fiscal health. This measure is a proxy for the budget deficits faced by states. The more negative this measure, the worse a state's fiscal health. It is reasonable to expect that the worse a state's fiscal health, the less the risk faced by a public official who supports a tax increase. The evidence using this measure is mixed. Berry and Berry (1990) find a negative but not statistically significant relationship, whereas Erekson et al. (1999) find a negative, statistically significant relationship.

It is likely that economic growth in a state is related to the state's fiscal health. States experiencing a recession may find it especially difficult to increase revenues using conventional forms of taxation, which may lead them to adopt a lottery. Alm, McKee, and Skidmore (1993) find that the larger the percentage change in real state personal income, the less likely is a state to adopt a lottery in a given period. Somewhat surprisingly, however, Alm, McKee, and Skidmore (1993) do not find either the percentage change in state tax revenues or the percentage change in state and local tax revenues to be statistically significant determinants of lottery adoption. One would expect these measures to be more closely tied to fiscal crises and thus to support the fiscal crisis argument.

Erekson et al. (1999) use somewhat different measures to capture the percentage change in the tax base in that they use the percentage change in per capita earnings in selected industries. They find some support for the fiscal health argument when they examine growth of earnings in the service sector.

Fiscal pressures might be lessened by intergovernmental transfers. Alm, McKee, and Skidmore (1993) examine both the percentage change in intergovernmental transfers to state government only and to state and local government jointly. Such transfers are not statistically significant determinants of lottery adoption. Caudill et al. (1995) and Mixon et al. (1997) gen- 
erate a similar finding using levels rather than percentage changes in intergovernmental transfers.

In summary, the fiscal health argument receives, at best, limited empirical support. One additional finding might provide some insights as to why the fiscal health argument applies only weakly to lottery adoption. Fink, Marco, and Rork (2004) found that overall state tax revenues declined with increased lottery sales. This net decline results from a decrease in sales and excise tax revenue, which is offset partially by an increase in income tax revenue. These changes in revenue for specific taxes are related to changes in both economic behavior and tax laws. For example, consumers are likely to substitute, to some degree, the purchase of lottery tickets for the purchase of goods subject to a sales tax. This substitution would increase lottery tax revenue and reduce sales tax revenue. In another study, Fink, Marco, and Rork (2003) find that lottery sales did not have a statistically significant effect on per capita state tax revenues. The implication of these studies is that the adoption of lotteries does not appear to provide even a partial solution to a state's fiscal problems.

\section{Election Cycles and the Political Decision Process}

Berry and Berry (1990) examine whether the timing of elections might affect the adoption of tax increases. They argue that lotteries will tend to be adopted in election years relative to other years because the lottery relative to other types of tax increases is generally more popular, a fact that elected officials are aware of and likely attempt to use to their advantage. ${ }^{26}$ Their relative popularity makes lotteries best suited for consideration and adoption in election years. Other taxes, because of their unpopularity, are more likely to be adopted in the year immediately following an election because this provides the maximum time prior to the next election for the electorate to forget about an unpopular tax increase. In addition, for those years that are neither an election year nor the year immediately following an election

\footnotetext{
${ }^{26}$ We are not suggesting that lotteries are uncontroversial, only less
} controversial as a revenue-increasing option. year, one should expect the probability of lottery adoption to fall somewhere in between-that is, to be less than it is in an election year but more than it is in the year following an election. Berry and Berry (1990) find empirical support for the preceding reasoning; however, Glickman and Painter (2004) do not.

The political decision process provides some limited information as to whether a lottery will be adopted in a given period. Alm, McKee, and Skidmore (1993) argue that political pressures for lottery adoption are likely to differ between states that use a referendum or an initiative compared with states that use a standard legislative process. They find that states using either a referendum or an initiative are more likely to adopt a lottery in a given year.

\section{Party Control}

Single-party control of a state's governorship and both houses of the legislature should make it easier for proposed legislation to be passed and signed into law. An empirical issue is whether such control increases the probability of lottery adoption in a given period. Berry and Berry (1990) hypothesize that such control would be associated with lottery adoption. They found, however, that such control decreased the probability of lottery adoption. One possibility is that a unified government will find it easier to increase existing taxes to achieve substantial revenue increases. Thus, a lottery is not needed to raise revenues. However, in terms of political control, divided governments might find it easier to reach agreement on a lottery, which is a relatively less controversial funding mechanism.

The connection between party control and lottery adoption has been explored in a number of other studies, but the results do not provide clear insights into the connection between party control and lottery adoption. For example, Alm, McKee, and Skidmore (1993) explored the role of party control by using separate dummies for Democratic control and Republican control versus shared control. Democratic control was a negative and statistically significant determinant of lottery adoption, whereas Republican control was not statistically significant. Glickman and Painter 


\section{Figure 2}

\section{Lottery Diffusion by Decade}

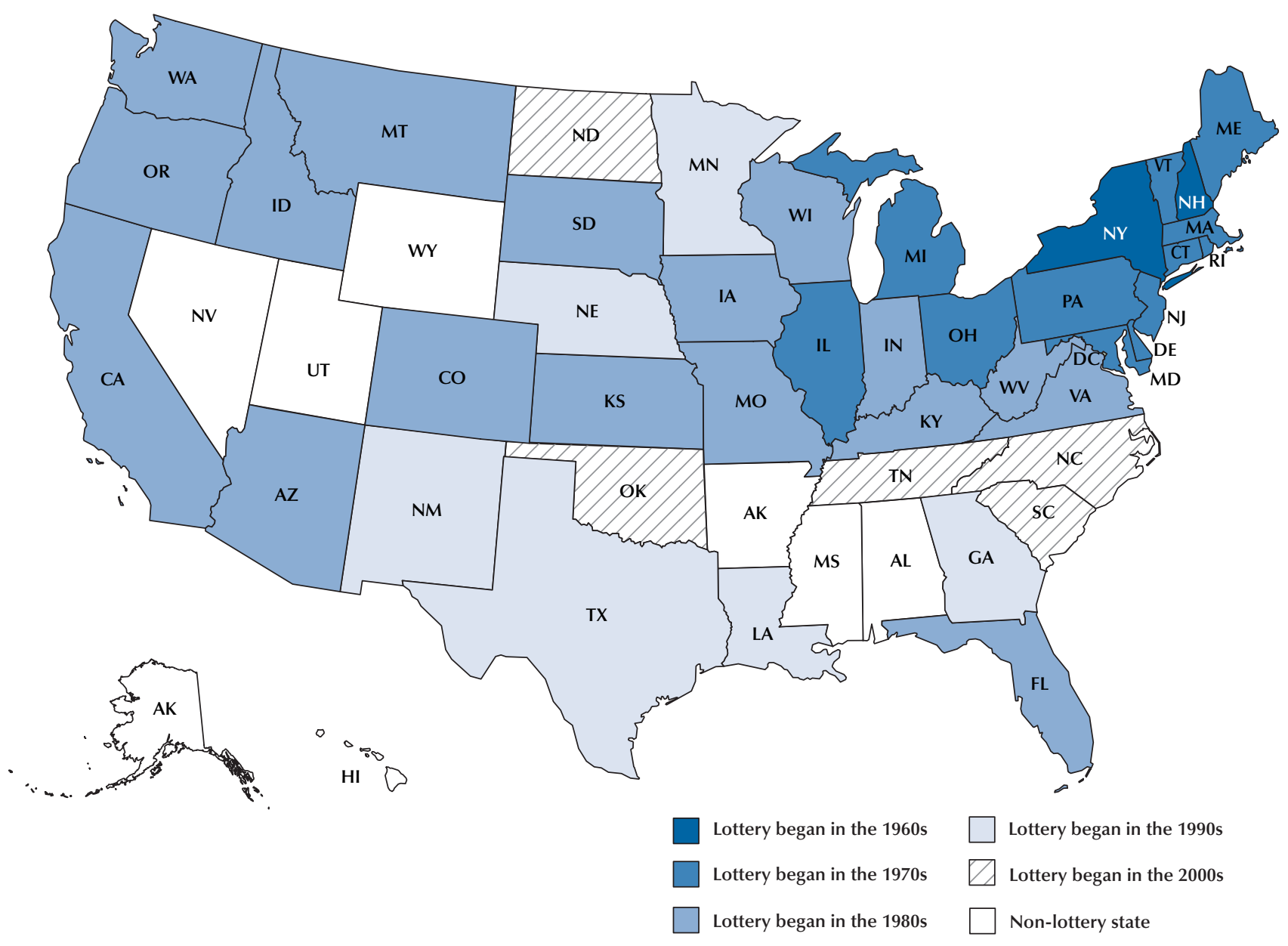

SOURCE: Data from Hansen (2004); North Carolina and Oklahoma information from news reports.

(2004) find a statistically significant, negative association between the percentage of a state's lower house that is Democratic and lottery adoption. Finally, Mixon et al. (1997) find no relationship between the percentage of a state's legislative bodies made up of the majority political party and lottery adoption.

\section{Regional Diffusion}

The spread of lotteries shows a geographic pattern (see Figure 2). Beginning in New Hampshire, lotteries spread to other states in New England, the Mid-Atlantic, and Great Lakes; they then spread throughout states in the Midwest and on the Pacific Coast and began appearing in states in the Plains and Rocky Mountains; most recently, they have spread to the South. In addition to Alaska and Hawaii, the only non-adoptee states are located in the South and the Rocky Mountains.

Hansen (2004) notes that the initial reluctance to adopt lotteries stemmed from concerns over the ability of lotteries to raise revenues both efficiently and without corruption. In addition, and more importantly from a geographic perspective, 
once lotteries were adopted, cross-border ticket sales were substantial. For example, prior to North Carolina's passage of a lottery, it was estimated that state residents were spending $\$ 100$ million per year on Virginia's lottery. ${ }^{27}$ Legislators and residents concluded that if residents were going to play the lottery, they would prefer that the spending and resulting tax revenues be kept within their state. ${ }^{28}$

To account for the possibility that tax competition between state governments might explain lottery adoption, the statistical connection between lottery adoption and a number of geographically based measures have been examined. The results suggest that lottery adoption by a state is related positively to the existence of a lottery in a neighboring state. The only exceptions can be found in Filer, Moak, and Uze (1988) and Glickman and Painter (2004). In both of these studies a dummy variable is used to identify whether an adjacent state had a lottery. On the other hand, this measure is also used by Alm, McKee, and Skidmore (1993), who found a statistically significant, positive relationship. Other studies, such as Davis, Filer, and Moak (1992), Erekson et al. (1999), Caudill et al. (1995), and Mixon et al. (1997), find a statistically significant relationship using the percentage of a state's border contiguous with states that have lotteries. Caudill et al. (1995) also find that the overall percentage of states already having adopted a lottery tended to increase the probability that a state would adopt a lottery in a given time period. Finally, Berry and Berry (1990) find that a given state was more likely to adopt, the larger the number of adjacent states that had previously adopted.

\section{Situational-Specific Determinants}

In addition to the sets of determinants associated with the adoption of taxes, there are many more constraints and considerations that might influence the adoption of a lottery. For example,

\footnotetext{
27 See Dube (2005).

28 The importance of cross-border ticket sales, however, does not cease when neighboring states both have lotteries. Tosun and Skidmore (2004) find that the introduction of competing games had an adverse effect on lottery revenues in West Virginia, a state that relies heavily on sales to players in nearby states.
}

Caudill et al. (1995) and Mixon et al. (1997) examine the impact of existing legalized gambling on lottery adoption. They argue that the larger a state's per capita tax revenue from legalized gambling, the less the need for an alternative revenue source and the more likely the organized opposition to a lottery because of the competitive threat that a lottery poses. Both studies find support for this argument. ${ }^{29}$

Tax exporting enables the citizens of a state to shift their tax burdens to those outside the state. Generally, taxpayers of a state would prefer to have taxpayers of other states provide the funding for their public services. In terms of lottery adoption, researchers have suggested that the shifting of lottery taxes is easier the larger a state's tourist industry. Tourists will take advantage of the opportunity to play the lottery and thus will provide lottery revenues. Based on the results of Filer, Moak, and Uze (1988), Davis, Filer, and Moak (1992), Caudill et al. (1995), and Mixon et al. (1997), this argument does not receive empirical support as indices of tax exporting that are based on tourism are not statistically significant determinants of lottery adoption.

The decision by a state to adopt a lottery is likely to be related to its prior fiscal decisions. States desiring to raise revenues have various ways to do so; however, some states have fewer alternatives than others. Filer, Moak, and Uze (1988) and Davis, Filer, and Moak (1992) explore the possibility that states without a sales tax are more likely to adopt a lottery than states with a sales tax. Neither study, however, finds a statistically significant relationship. Glickman and Painter (2004) examine the influence of state tax and expenditures limits on lottery adoption and find limits on assessment increases are related to lottery adoption. Finally, Martin and Yandle (1990) examine the impact of state balanced budget requirements and do not find a statistically significant relationship between balanced budget requirements and lottery adoption.

\footnotetext{
${ }^{29}$ In contrast, Davis, Filer, and Moak (1992) find a statistically significant, positive relationship between per capita tax revenue from gambling and lottery adoption. They stress that this finding reflects a preference for gambling.
} 
As suggested earlier, the preferences of the electorate are likely to influence political decisions in a democracy. Caudill et al. (1995) and Mixon et al. (1997) use whether a state already has legalized gambling as an indicator of a state's preferences toward lotteries. Despite the noteworthy exception of Nevada, both studies find that if a state has legalized gambling it is more likely to adopt a lottery. In addition, the preferences of two groups, the elderly and religious groups, have been examined.

Alm, McKee, and Skidmore (1993) argue that the elderly tend to oppose most tax increases, but that they might not oppose a form of tax increase that can be viewed as much more voluntary than other forms of tax increases. Using the percentage of a state's population that is 65 and older, however, neither Alm, McKee, and Skidmore nor Glickman and Painter (2004) find a statistically significant relationship.

When one thinks of those in opposition to lottery adoption, one generally starts with religious groups. The lottery battle in Tennessee illustrates this fact. Bobbitt (2003) noted that the largest and most influential anti-lottery group, the Gambling Free Tennessee Alliance, consisted primarily of church groups, such as the Tennessee Baptist Convention, Tennessee Catholic Public Policy Group, and the United Methodist Church. Generally, the most strident opposition by many church groups is based on the belief that gambling is immoral. In addition, other issues such as the prospects of deceptive advertising, the regressivity of the lottery tax, and the prospects for gamblingrelated problems have provided the basis for opposition. With respect to gambling-related problems, the Gambling Free Tennessee Alliance stressed the increased incidence of compulsive gambling and the associated social problems of increased crime, suicide, drug use, and job loss.

Various proxies have been used to measure the preferences of religious groups. Frequently used proxies indicating opposition to gambling-used by Filer, Moak, and Uze (1988), Berry and Berry (1990), Martin and Yandle (1990), Caudill et al. (1995), and Mixon et al. (1997)—are either the percentage of a state's population that is Southern Baptists or, more broadly, that are fundamentalist
Christians. ${ }^{30}$ Excluding Filer, Moak, and Uze (1988), these measures are negative and statistically significant determinants of lottery adoption.

Two other proxies have also been used.

Erekson et al. (1999) use the increase in the percentage of state population that is Protestant. They find a statistically significant, negative relationship with lottery adoption. The final proxy that has been used is the percentage of Catholics in a state. Despite the fact that a Catholic group was part of the Gambling Free Tennessee Alliance, Catholics are often viewed as having a greater preference and tolerance for gambling because of their use of bingo and other games for fundraising purposes. In addition, a larger percentage of Catholics in a state may indicate a smaller percentage of those with religious affiliations who would oppose lotteries. Alm, McKee, and Skidmore (1993) and Glickman and Painter (2004) use such a measure; the former finds a statistically significant, positive relationship with lottery adoption, whereas the latter does not find a statistically significant relationship.

Mixon et al. (1997) argue that long-stable societies are more likely to have the special interest groups that provide such stability. These special interest groups-professional associations, labor unions, trade associations, and other coalitions that attempt to shift the distribution of income in their favor-are more likely to exist in older states, which is measured by the years since statehood. Therefore, in light of the redistribution associated with lotteries, the older the state, the more likely a lottery. Mixon et al. find support for this argument.

\section{SUMMARY AND CONCLUSIONS}

Geographic, economic, and political factors have all played roles in the spread of lotteries as well as the decision of some states not to adopt lotteries. On the basis of previous literature, we

\footnotetext{
${ }^{30}$ Fundamentalist Christians encompass those Protestant denominations who believe in the inerrancy of the Bible, the virgin birth of Jesus Christ, the doctrine of substitutionary atonement, the bodily resurrection and return of Christ, and the divinity of Christ. For more details, see "What Is a Fundamentalist Christian?" by Dale A. Robbins at www.victorious.org/chur21.htm.
} 
suggest that explanations for lottery adoption can be organized into six categories: (i) economic development, (ii) fiscal health, (iii) election cycles, (iv) political party control, (v) regional diffusion, and (vi) situational-specific determinants.

In terms of economic development, one consistent finding is that higher levels of per capita state income are positively associated with lottery adoption. This finding supports the view that, because those with low incomes bear a higher lottery tax burden than those with high incomes, lotteries are a mechanism for those with high incomes to shift some of their tax burden to those with low incomes. Another explanation is that higher state per capita income is associated with more potential revenue from a lottery.

Relatively more urban states have been found to be more likely to have adopted lotteries. A similar comment pertains to more densely populated states. In the former case, the revenue potential argument hinges on the possibility of relatively lower administrative costs in states with relatively larger urban populations. In the latter case, the argument hinges on the possibility of relatively greater values of revenue per dollar of administrative cost due to more potential purchasers of lottery tickets per sales outlet.

Although fiscal crises are hypothesized to increase the probability that a state will approve a new tax, a review of existing studies raises doubts about the importance of this explanation for lottery adoption. The various proxies that have been used to capture a state's fiscal health fail to have a consistent relationship with lottery adoption. One explanation for the absence of a statistically significant relationship between a state's fiscal health and lottery adoption is that lottery revenues are unlikely to provide sufficient revenues, especially in the near term, to alleviate a fiscal crisis.

With regard to political factors that might influence lottery adoption, some empirical support exists for what is termed an election cycle explanation. The political decision to raise taxes is always resisted by at least some individuals and groups; however, the lottery relative to other forms of tax increases is popular. From a politician's point of view, especially one who desires to be re-elected, the consideration of tax increases in an election year is very risky. As a result, lotteries, which can be viewed as a voluntary tax payment relative to other taxes, are best suited for consideration and adoption in election years. Moreover, even if raising state tax revenues is not an issue, the popularity of lottery adoption might make an election year an especially good time to adopt a lottery.

The nature of the decision process does play a role in whether a lottery is ultimately adopted. Relative to a legislative process that relies solely on approval by a state's legislature prior to a signing by the governor, states that use either an initiative or a referendum as part of the approval process are more likely to have lotteries. The importance of the decision process might be the key to understanding the empirical findings with respect to party control.

Findings with respect to party control and lottery adoption fail to provide clear insights concerning the impact of single-party control of a state's governorship and both houses of the legislature. Such control should make it easier for the controlling party to pass and sign into law its desired legislation. Nonetheless, a consistent empirical relationship between party control and lottery adoption is not identified in the existing studies. Party control might have a lessened effect in states using either an initiative or a referendum because of the direct voicing of the electorate's preferences.

Our review of existing studies highlights the importance of geography in the spread of lotteries across the United States. Regardless of the measure used to account for lotteries in neighboring states, it is clear that lottery adoption by a state is related positively to the existence of lotteries in a neighboring state or states. This finding is a clear indicator of the impact of tax competition between states. State legislators and their constituents have concluded that if residents are going to play the lottery, they would prefer that the spending and tax revenues be kept within their state.

It is also reasonable to think that the electorate in a state that already has legalized gambling would be inclined to support lottery adoption. Despite the absence of a lottery in Nevada, empiri- 
cal support for this line of thinking exists. States with relatively more police and police expenditures are also more likely to have adopted lotteries. Only limited support exists for the argument that prior fiscal decisions that limit a state's tax revenue potential provide a motivation for lottery adoption.

In terms of the preferences of specific groups, both the elderly and religious groups have been examined. For the former group, there is no statistically significant relationship between the percentage of a state's population that is elderly and lottery adoption. On the other hand, it is clear that the larger the relative size of a religious group that opposes lottery adoption the less likely that a state will adopt a lottery. Religious opposition to lotteries is undoubtedly a key reason that lottery adoption by states in the South tended to lag lottery adoption by states in the rest of the country.

One final result suggests that long-stable societies, which are more likely to have entrenched special interest groups, are more likely to have lotteries. Because interest groups attempt to shift the distribution of after-tax income in their favor, lotteries are more likely because of their redistributive effects. This final result is simply one of the many illustrations in this review of lottery adoption showing the connection between economic motivations and political results.

\section{REFERENCES}

Alm, James; McKee, Michael and Skidmore, Mark. "Fiscal Pressure, Tax Competition, and the Introduction of Lotteries.” National Tax Journal, December 1993, 46(4), pp. 463-76.

Becker, Gary S. “A Theory of Competition among Pressure Groups for Political Influence.” Quarterly Journal of Economics, August 1983, 98(3), pp. 371400.

Berry, Frances Stokes and Berry, William D. "State Lottery Adoptions as Policy Innovations: An Event History Analysis." American Political Science Review, June 1990, 84(2), pp. 395-415.

Berry, Frances Stokes and Berry, William D. "Tax Innovation in the States: Capitalizing on Political
Opportunity," American Journal of Political Science, August 1992, 36(3), pp. 715-42.

Blanch, Ernest. "Lotteries and Pools." American Statistician, 1949, 3(1), pp. 18-21.

Bobbitt, Randy. "The Tennessee Lottery Battle: Education Funding vs. Moral Values in the Volunteer State." Public Relations Quarterly, Winter 2003, 48(4), pp. 39-42.

Bonner, Lynn. "Lobbyists Often the Ghost Writers of State Laws." The News \& Observer, October 26, 2005; www.newsobserver.com/656/v-print/story/ 351031.html.

Caudill, Stephen B.; Ford, Jon M.; Mixon, Franklin G. and Peng, Ter Chao. "A Discrete-Time Hazard Model of Lottery Adoption." Applied Economics, June 1995, 27(6), pp. 555-61.

Clotfelter, Charles T. and Cook, Philip J. Selling Hope: State Lotteries in America. Cambridge, MA: Harvard University Press, 1989.

Clotfelter, Charles T. and Cook, Philip J. "On the Economics of State Lotteries." Journal of Economic Perspectives, 1990, 4(4), pp. 105-19.

Clotfelter, Charles T.; Cook, Philip J.; Edell, Julie A. and Moore, Marian. "State Lotteries at the Turn of the Century: Report to the National Gambling Impact Study Commission.” Report, Duke University, 1999.

Davis, J. Ronnie; Filer, John E. and Moak, Donald L. "The Lottery as an Alternative Source of State Revenue." Atlantic Economic Journal, June 1992, 20(2), pp. 1-10.

DeBoer, Larry. "Administrative Costs of State Lotteries." National Tax Journal, December 1985, 38(4), pp. 479-87.

Dube, Jonathan. "N.C. Watches as States Add Lotteries," 2005; www.jondube.com/resume/charlotte/lottery.html.

Erekson, O. Homer; Platt, Glenn; Whistler, Christopher and Ziegert, Andrea L. "Factors Influencing the Adoption of State Lotteries." Applied Economics, July 1999, 31(7), pp. 875-84. 


\section{Coughlin, Garrett, Hernández-Murillo}

Filer, John E.; Moak, Donald L. and Uze, Barry. "Why Some States Adopt Lotteries and Others Don't." Public Finance Quarterly, July 1988, 16(3), pp. 259-83.

Fink, Stephen C.; Marco, Alan C. and Rork, Jonathan C. "The Impact of Lotteries on State Tax Revenues." Proceedings from the Ninety-fifth Annual Conference on Taxation, November 14-16, 2002, Orlando, FL; minutes of the annual meeting of the National Tax Association, November 14, 2002. Volume 27. Washington, DC: National Tax Association, 2003, pp. 1169-72.

Fink, Stephen C.; Marco, Alan C. and Rork, Jonathan C. "Lotto Nothing? The Budgetary Impact of State Lotteries." Applied Economics, December 2004, 36(21), pp. 2357-67.

Fisher, Ronald. State and Local Public Finance. Chicago: Irwin, 1996.

Garrett, Thomas A. "A Test of Shirking under Legislative and Citizen Vote: The Case of State Lottery Adoption." Journal of Law and Economics, April 1999, 42(1, Part 1), pp. 189-208.

Garrett, Thomas A. "Earmarked Lottery Revenues for Education: A New Test of Fungibility." Journal of Education Finance, Winter 2001, 26(3), pp. 219-38.

Garrett, Thomas A.; Wagner, Gary A. and Wheelock, David C. "A Spatial Analysis of State Banking Regulation.” Papers in Regional Science, November 2005, 84(4), pp. 575-95.

Glickman, Mark M. and Painter, Gary D. "Do Tax and Expenditure Limits Lead to State Lotteries? Evidence from the United States: 1970-1992." Public Finance Review, January 2004, 32(1), pp. 36-64.

Hansen, Alicia. "Lotteries and State Fiscal Policy." Background Paper No. 46, Tax Foundation, October 2004.

Hansen, Susan B. The Politics of Taxation: Revenue without Representation. Westpoint, CT: Praeger, 1983.
Hernández-Murillo, Rubén. "Strategic Interaction in Tax Policies Among States.” Federal Reserve Bank of St. Louis Review, May/June 2003, 85(3), pp. 47-56.

Hersch, Philip J. and McDougall, Gerald S. "Voting for 'Sin' in Kansas." Public Choice, May 1988, 57(2), pp. 127-39.

Martin, Robert and Yandle, Bruce. "State Lotteries as Duopoly Transfer Mechanisms." Public Choice, March 1990, 64(3), pp. 253-64.

McCormick, Robert and Tollison, Robert. Politicians, Legislation, and the Economy: An Inquiry into the Interest Group Theory of Government. Boston: Martinus Nijhoff, 1981.

Mixon, Franklin G. Jr.; Caudill, Steven B.; Ford, Jon M. and Peng, Ter Chao. "The Rise (or Fall) of Lottery Adoption within the Logic of Collective Action: Some Empirical Evidence." Journal of Economics and Finance, Spring 1997, 21(1), pp. 43-49.

Oster, Emily. "Are All Lotteries Regressive? Evidence from PowerBall.” National Tax Journal, June 2004, 57(2, Part I), pp. 179-87.

Robbins, Dale A. "What Is a Fundamentalist Christian?" 1995; www.victorious.org/chur21.htm.

Rodrik, Dani. "Political Economy of Trade Policy," in Gene M. Grossman and Kenneth Rogoff, eds., Handbook of International Economics. Volume III. Princeton, NJ: Elsevier, 1995, pp. 1457-94.

Spindler, Charles. "The Lottery and Education: Robbing Peter to Pay Paul." Public Budgeting and Finance, Fall 1995, 15(3), pp. 54-62.

Tosun, Mehmet Serkan and Skidmore, Mark. "Interstate Competition and State Lottery Revenues." National Tax Journal, June 2004, 57(2, Part 1), pp. 163-78. 